\title{
ONLINE ASSESSMENT IN MOODLE: A FRAMEWORK FOR SUPPORTING OUR STUDENTS
}

\author{
P. Padayachee \\ Academic Support Program for Engineering (ASPECT) \\ University of Cape Town \\ Cape Town, South Africa \\ e-mail: pragashni.padayachee@uct.ac.za
}

\section{S. Wagner-Welsh*}

Mathematics and Applied Mathematics Department

e-mail: Shirley.wagner-welsh@nmu.ac.za

\author{
H. Johannes* \\ Centre for Teaching, Learning and Media \\ e-mail: hermien.johannes@nmu.ac.za
}

*Nelson Mandela University

Port Elizabeth, South Africa

\section{ABSTRACT}

The strong performance of writers on the national school exit examinations mean that the access to higher education has never been more open than it is at present. The large groups of students that now occupy our lecture halls undoubtedly present teaching, learning and assessment challenges unfamiliar to the lecturing corps. Higher education will have to rethink how we engage in this arena to ensure students are successful.

Appropriate online assessment may address some of the challenges faced in the teaching and learning setting. This article describes, the experiences of 392 mathematics students, undertaking their assessments via Moodle at a University in the Eastern Cape of South Africa. Student experiences informed the design of a supportive environmental framework for online assessment.

The theoretical lens for this research study is framed by mastery learning, student experience and online assessment. The research reported on in this article highlights one aspect of the project: the third phase of the action research cycle, namely, the observation the implementation of online assessment.

Examples from two blended learning Moodle courses highlight some of the experienced difficulties and successes. The lessons learnt informed the online assessment design and implementation of supportive environments for online assessment. The knowledge gained from this study culminated in a 4 Pillar Supportive Online Assessment Framework for 
Blended Learning environments, which could contribute to an improvement in online assessment practices. This research article concludes with a description of the supportive environmental framework for online assessment as well as possible implications for higher education.

Keywords: online assessment, Moodle, supportive learning environment, student experience, higher education, blended learning, 4 Pillar Supportive Online Assessment Framework

\section{INTRODUCTION}

With the increased intake of students into higher education in South Africa, it has become necessary to seek new ways to engage effectively in teaching, and to promote learning, in spite of large classes. In the past decade, the introduction of technology into the teaching and learning arena has initiated much excitement for learning. This integration of online technology with face to face contact is becoming more and more common in Higher Education classes. According to Allen, and Seaman (2014), "ninety per cent of academic leaders believe that it is Likely or Very Likely that a majority of all higher education students would be taking at least one online course in five years' time". Indications are that the blended learning approach, which can be described as a combination of face to face and online learning on a continuum spanning time, space and distance, is becoming the global norm in higher education (Engelbrecht 2005; Liaw, Huang, and Chen 2007; Allen, and Seaman 2014). As Norberg, Dzuiban and Moskal $(2011,207)$ indicate "blended learning may be the new normal for course delivery". This has an implication for assessment of student learning practices within a technology enhanced environment, and even more so for assessing large student groups.

The advances in technology, and the new ways in which our students learn, compel us to integrate technology into our teaching and learning environment. The benefits which online assessment bring to technology enhanced education may address some of the teaching, learning and assessment challenges related to large classes, as well as the low motivation and mathematics under-preparedness of students. For example, availability anywhere, anytime, on any device; with multiple opportunities for mastery learning at own pace, excellent immediate formative feedback, and automated grading and reporting are some of the benefits of online assessment. The purpose of this article is to describe experienced difficulties, successes, and the lessons learned from online assessment implementation. These culminated in a 4 Pillar Supportive Environment Framework for Online Assessment to inform online assessment design, enabling educators to move forward with supportive environments for the online assessment of student learning. 
This action research study was conducted at a South African University. The study population included two mathematics service courses. A total of 392 students, taking their assessments via Moodle, were surveyed. The student population has a very diverse mathematical background and these students generally register for these courses to satisfy the prerequisites of various degree programmes. Although 86 per cent of the participants were enrolled in the Business and Economic Science Faculty, the other participants were from the Arts, Education, Engineering Built Environment \& IT, Law, Health Sciences and Science Faculties.

The large numbers of students, with diverse mathematical backgrounds and with various mathematical focal points as informed by their courses of study renders the class even more challenging to teach. Students typically wish to spend little time with the concepts taught simply to pass the course since these are service courses and not their main course of study. It is often the case that these types of learning result in a superficial understanding of the concepts taught and yet are masked by high pass rates. The onus rested on the lecturers to entice students to engage with the concepts, and to enhance their understanding of the mathematics taught.

Consequently, a low-stake online tutorial system was developed. The students had to complete weekly tutorials on the mathematical concepts covered during the face to face lectures in a particular week. To encourage student participation in the tutorials, marks were awarded; and in order to enhance the students' understanding of the concepts taught, they had first to earn 70 per cent in a practice tutorial covering the same concepts as the main tutorial. The students had access to all other resources online, such as course notes, lecture slides and various links to videos on the concepts taught whilst doing the tutorials.

Gibbs $(1999,41)$ suggests that: "Assessment is the most powerful lever teachers have to influence the way students respond to courses and to behave as learners". This view is supported by Cowan $(2005,2)$, who says that "Assessment is the engine which drives student learning". There are different types of assessment but the current study will focus on formative assessment. SAQA (2014) describes formative assessment as: "A range of formal, non-formal and informal ongoing assessment procedures used to focus teaching and learning activities, in order to improve student attainment, or that are required for the purpose of a year mark" (Standard Glossary of Terms, SAQA 2014). In this research study the main focus of assessment was to: (1) Inform learners and lecturers of the learning progress; (2) to improve students' interaction with the concepts taught; and (3) to enhance their learning. Formative online assessment is developmental in nature, since the aim is to enhance student learning by providing prompt feedback, 
opportunities for self-assessment focusing on assessment for, and as learning, within the context of a technology enriched environment.

The focus of the study is on the elements of the learning environment that support student learning, as described by them, and less on the technical aspects of online assessment. Noting students' experiences of the learning environment is an important consideration in the teaching and learning process, as Machado and Tao (2007, S4J7) advocate. They say that, in order for assessment to "be considered effective, the users' experience must be studied and analysed, to provide the optimal solution to meet the pedagogical needs of both faculty and students".

Analysis of student experiences allows lecturers to choose teaching methods that would help students learn, and help them to create more meaningful learning experiences. In keeping with the action research methodology, this requires that all the stakeholders participate, in order to enhance the teaching and learning experience. Eliciting students' experiences has a vital role to play in this process. Reason and Bradbury (2007, 9-10) suggest that the "participatory process of action research seeks to bring together action and reflection, theory and practice, in participation with others, in the pursuit of practical solutions to issues of pressing concern to people, and more generally, the flourishing of individual persons and their communities".

Therefore, this article includes a section on the theoretical underpinnings for the study, and how these different lenses illuminate and inform the online assessment design. It describes the implementation and observation in the third phase of the action research cycle.

\section{THEORETICAL UNDERPINNINGS}

This study has used theoretical underpinnings from the mastery learning, student experience and online assessment fields as theoretical lenses.

\section{Mastery Learning}

Various studies and meta analyses of mastery learning over the past 50 years have found consistently positive effects for teaching, learning and assessment (Guskey 2008; Kulik, Kulik and Bangert-Drowns 1990; McGaghie 2015; Groen et al. 2015). According to Davis and Sorrell (1995) the "goal of mastery learning is success for the student. It is asserted that success in achievement, attitude and motivation in the educational or learning environment makes learning more effective" (Davis and Sorrell 1995). The greatest impact, however, lies in student success via self -regulated learning. 
Anderson $(1975,1)$ describes mastery learning as learning, which "can be described as a set of group based, individualized, teaching and learning strategies, based on the premise, that virtually all students can and will, in time, learn what the school has to teach". According to Bloom, mastery learning is based on the assumption that most students can master the required knowledge, attitudes and skills, within the context of sufficient time and learning methods opportunities. "It is the task of instruction to find the means, which would enable our students, to master the subject under consideration" (Bloom 1968, 1).

The mastery learning approach within the Moodle online environment enables students to make optimal use of its dynamic nature, in order to provide continual feedback on how successful they are. Not only is this in meeting the learning objectives, but also by identifying areas for improvement for both the students and the lecturers.

The application of online assessment within a mastery learning approach, could optimize results, reduce administrative time, promote immediate feedback, provide grades and progress by the press of a button, and provide multiple opportunities for practice - drawn from a variety of questions in large question banks. Another invaluable feature of online assessment within the Moodle environment is its inherent learning management system capabilities. These include the capacity to manage teaching, student learning, and all the facets of assessment, such as the tools for creating reports, analysing grades and student learning patterns, student participation, assessment design, branching, score analysis and interpretation and learning analytics. For large student groups, the benefits of these features are invaluable. Groen et al. (2015) reported positive outcomes for, and proposed mastery learning as a solution to the problems facing first year STEM students in their mathematics subjects. Various authors, including McGaghie (2015) and Inui (2015) support the notion that a mastery approach to education contributes to student learning in the 21 st Century.

\section{Student experience with and the perceptions of online assessment}

Formative assessment is not only "an integral part of effective teaching" (Glossary of Education Reform), but also a good online learning experience (Tilghman 2011, 34; Abedi 2014, 2). To facilitate online assessment lecturers "must construct successful assessment strategies and frameworks that are specifically designed for online learning environments" (Tilghman 2011). The results from a study reporting on the implementation of e-assessment in a Chemical Engineering module (Sorensen 2013) highlighted a number of design features for student success, and concluded that e- 
assessment quizzes "were mainly beneficial to the weaker students, i.e. those with lowest overall grade point averages, as it gave them an opportunity to go over key aspects of the material in their own time".

Students' experiences, perceptions and satisfaction with online assessment are linked to various student success factors inter alia self-regulation, time management, selfevaluation, and prompt feedback on performance (Kauffman 2015). Mastery learning by its very nature enables these factors; and it is supported by student perceptions on academic success, attitudes towards learning and mathematical confidence, as well as the retention of content etc. (Groen et al. 2015, 156-158). The option of re-taking online mastery learning assessments is viewed as a positive step for enhanced learning and comprehension (Abedi 2014, 6).

The above mentioned theoretical considerations, underpin the design, development and implementation of the online assessments relevant to this study. A total of 10 practice tutorials and 10 online mastery learning tutorials, in total 20 online assessments, were administered and completed by the participants.

\section{A supportive learning environment}

Holtz $(2006,2)$ lists seven elements of supportive learning environments, as follows: (1) "Safety of physical plant"; (2) "shared leadership practices"; (3) "structured personalised learning communities"; (4) "student centred practices"; (5) "caring relationships"; (6) "discipline and self-management practices"; and (7) "active involvement" (Holtz 2006). Padayachee $(2010,10)$ asserts that a "supportive learning environment is learner centred and interactive; it encourages participation; it engages learners collaboratively; it acknowledges learners' different styles of learning; it challenges learners to set goals; it instils self-confidence; and it provides resources and mentoring, in order for learners to succeed".

The Framework for 21 st Century Learning (n.d.) states that: "Perhaps a better way to think of 21 st century learning environments is as the support systems that organize the condition, in which humans learn best - systems that accommodate the unique learning needs of every learner - and support the positive human relationships needed for effective learning. Learning environments are the structures, tools, and communities that inspire students and educators to attain the knowledge and skills the 21 st century demands of us all” (The Framework for 21st Century Learning n.d., 21; Abedi 2014, 9).

Within the blended mastery learning online assessment context, students' learning experiences are influenced by various interactions, such as between people, subject 
content, and the learning environment. Anderson $(2004,273)$ states that "the pervasive effect of the online medium creates a unique environment for teaching and learning. The most compelling feature of this context is the capacity for shifting the time and place of the educational interaction".

\section{THE RESEARCH DESIGN}

Manchester, Ralph and Shipova (2005) view "action research as an important link between research and teaching, particularly when the research is actively conducted with the intention of informing teaching and learning; and it challenges the ways of incorporating technology into the curriculum" (Manchester et al. cited in Padayachee, Boshoff, Olivier and Harding 2011).

For this study, the four phases (planning, acting, observing and reflecting) in the action research cycle (Rossouw, 2009, 9) include the following steps:

- $\quad$ Selecting a focus (The implementation of online assessment of student learning);

- Clarifying theories (mastery learning, student experience of online assessment, and a supportive learning environment);

- Research questions: 1. What are students' experiences of online assessment via Moodle? 2. What elements contribute to a supportive online environment for assessment?);

- Collecting and analysing the data to identify students' experiences and perceptions, and to determine the story told by the data;

- $\quad$ Reporting and interpreting the results (lessons learned, 4 Pillar Supportive Online Assessment (SOA) Framework);

- Taking informed action (reflect, plan and implement changes to start next action research cycle).

The research reported on in this article highlights one aspect: the third phase of the action research cycle, namely, to observe the implementation of online assessment (see Figure 1). The purpose of this phase was to understand the students' experiences of this online implementation of assessment; and in so doing, to determine the elements that contribute to a supportive online environment for assessment. 


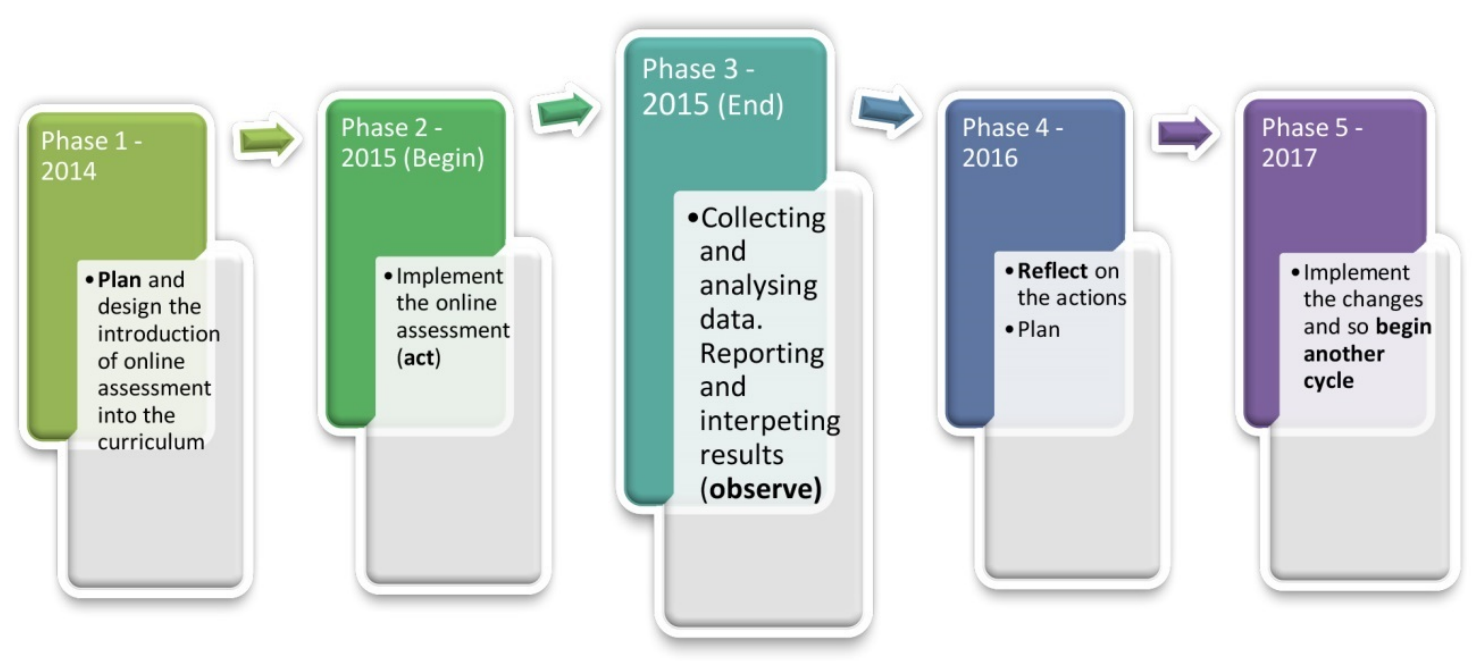

Figure 1: The action research cycle of online assessment in a mastery blended learning framework

\section{THIRD PHASE IN THE ACTION RESEARCH CYCLE}

The observation phase included: (1) Collecting and analysing the data; and (2) reporting and interpreting the results. Applying mastery learning design principles for this study included a division of the content into formative online assessment (tutorial) units of learning with clearly defined learning outcomes. The students worked throughout the online assessments, at their own pace, with a free choice of the number of repetitions, to reach a mastery level of at least 70 per cent. Those students who do not achieve mastery can be remediated through the available online resources, immediate feedback on question level, and via system progress reports. The blended learning context provided opportunities for face to face discussions, and additional support by lecturers, tutors and peers.

\section{COLLECTING AND ANALYSING THE DATA}

\section{Demographic information - student profile}

A total of 392 students from two mathematics for business courses given on different campuses participated in the study. One of the mathematics for business courses serviced diploma students; whilst the other was offered to degree students.

The survey was taken at the end of the fourteen week course. One hundred and sixtythree participants were Xhosa speaking; 121 were English speaking; and fifty-five were Afrikaans speaking. Two hundred and twenty-four (57\%) were females. Three hundred and twenty-four participants (84\%) were under twenty one years of age. Fifteen (4\%) were older than 30 years of age. All of the respondents were undergraduates. Both courses 
cater for workers studying part-time, in order to further their education. Fifteen part time students (4\%) took part in the study. Fifty-five per cent of the participants possessed laptops; 30 per cent had smartphones; while three per cent reported having desktops.

During the observation phase of the action research cycle, a total of 392 students completed a questionnaire online. This questionnaire contained 16 closed ended and 3 open-ended questions aimed at capturing students' self reported experiences and comments regarding online assessment within a mastery learning approach. The closed questions included sections on: (1) The biographical data; (2) the available tools and technologies; (3) the access issues; and (4) the Moodle resources, activities, and assessment; and (4) student learning.

The open-ended questions asked for comments on: "Ways to improve"; "positive aspects"; and "negative aspects". An analysis of the data was undertaken by the researchers independently, in order to identify any themes in the students' responses. The themes were further discussed in the research team, until consensus was reached. Four themes, namely: physical, intellectual, emotional and virtual learning environments were identified. The reported experiences and comments of the participants were grouped into sub themes (elements) of online assessment relating to the physical, intellectual, emotional and virtual learning environments. Verbatim texts were categorised and recorded.

The students' response to both open-ended and closed questions in the questionnaire, the discussion on students' experiences and elements of online assessment relating to the physical, intellectual, emotional and virtual learning environments are reported in the tables in Appendix A.

\section{REFLECTIONS, LESSONS LEARNT AND RECOMMENDATIONS}

Reflections and lessons learnt under the themes of the physical learning environment, the intellectual learning environment, the emotional learning environment and the virtual learning environment will now be discussed.

\section{The physical learning environment}

The open-ended section, referring to the physical learning environment contained students' reflections on network related issues, computer laboratory availability, power outages and disability issues. Network speed affects the efficiency of the online assessment system. "I honestly think online tutorials are at their best, the only problem is when the network freezes or anything of the sort". 
Students accessing the online environment remotely reported slow WIFI connectivity. Access speeds from within the computer laboratories also fluctuated. Online assessment exposes students to what Volery and Lord (2000) called "the implications of computer networks". Volery and Lord highlighted the importance of convenient access and quick document exchange times. Many students alluded to the slow connectivity, as indicated by this comment: "Sometimes the system is quite slow; and this reduces your time available to solve questions".

In the environment under discussion here, it is important to acknowledge that slow connectivity and internet speed exist. Design features, such as additional attempts and additional time have to be built in - to compensate for possible connectivity problems.

Although online tutorials replaced classroom based written tutorial assessment, the blended learning approach provided face to face contact between people, such as interaction with peers, lecturers, as well as teaching and technology assistants. The importance of the different levels of interaction in a supportive learning environment is evident from comments, such as:

"The online tutor is perfect, as it is at the moment. The explanations on it tend to become ambiguous at times; but most of the time it is OK."

"We can help each other with friends."

The blended mastery learning approach extended the physical classroom space to an online space, to span time distance and location, which allowed for creative instructional design to minimise negative elements and optimise positive elements in the physical learning environment. For example, face to face communication extended to the virtual environment.

Although specific laboratory space was made available to students on one campus, students on another campus had to use the general university laboratories. More efficient scheduling of laboratory space could help alleviate laboratory space issues. Laboratory space needs to be allocated more regularly, to enable students who do not have computers, internet access, or had technical or academic issues with tutorials, to complete their tutorials on campus. This encouraged those students who have internet access at home to attempt their tutorials at home. The university should consider extending laboratory availability times and encourage the borrowing of devices, if the library can provide such devices.

During the duration of the study, the country suffered power outages. These outages affected students' planning; and more flexibility of time was required, especially since 
these assessments were developed to support learning. The importance of student training to equip them with the necessary skill and self-confidence to utilise the online environment, should never be underestimated. Assistants or tutors should be enlisted to help with empowering students to become familiar with computers, and to teach students time management skills, and give them a way to plan their work schedules. The study indicates that the department should set up a practical tutorial, which could run for an entire week, right at the beginning of the course, with the available tutor help. In addition, the results of the study indicate that students should be encouraged to download questions, enabling them to work offline, and so alleviate the issue of slow or no connectivity. The Moodle learning management system supported the delivery, grading and reporting of the online assessments.

Two students reported suffering from an eye condition, which was made worse by staring at the screen. This highlights the importance of learning design to cater for disabilities, such as paper-based substitutes for online assessments, where appropriate; large screens and specialised software combined with audio clips. The blended mastery learning approach is well suited to accommodate students with various disabilities, as design features could be customised to include more time allowances for students with learning disabilities. Other features may include technology adaptations to cater for specific disabilities. Therefore, poor design for disabilities could be listed as a negative in a supportive learning environment. Careful inclusive design should cater for students with disabilities.

Minimising negative elements in the physical learning environment is challenging for all role players; and it emphasises the importance of people in the physical learning environment. Students, lecturers, tutors and peers support each other; and the following comment is a good example of distributed scaffolding (an important element in a supportive learning environment): "I enjoyed doing my tutorials on (Moodle); because it was less pressure, I completed them in a relaxed environment together with the help of friends here and there".

Distributed scaffolding includes support from people (lecturers, peers, and assistants) within mastery learning approaches, supported by resources, multiple online assessment opportunities, with prompt, customised feedback. Peer support was highlighted as being particularly important, motivating students and helping them to learn. "We can help each other as friends".

Another sub theme that emerged from this category was resources. Some students expressed their satisfaction with the available resources; whereas other students requested 
more exercises, questions and tests. Sufficient resources aid students' mastery learning experiences. Resource material should be reviewed, to ensure that sufficient resource material is available for all the students.

\section{The intellectual learning environment}

Sub themes arising in the intellectual learning environment highlight the need for students to have adequate time management skills. Time management comments vary from pleas to extend the deadlines to requests for shorter deadlines. "You must be more strict when it comes to time of starting and finishing of each tutorial. We tend to forget how important time management is".

Incorporating a day long time management schedule / example in the first year orientation programme could assist students to manage their time better. This is an important issue, and an important skill to teach, as it is needed in the world of work, and life in general. Song, Singleton, Hill and Koh (2004) identified time management, as one of the key components that make learners successful in an online environment.

In the quest to embrace all the different learning styles, and to encourage students to keep to a time frame, time penalties would be put into place to encourage students to manage their time effectively. These comments should be mirrored against online assessment and mastery learning design principles for best practice. For example, designers need to keep a balance between sufficient time for task completion and extended timeframes, so as not to have a negative effect on course dynamics. The time element plays different roles in the supportive learning environment; and it should be skilfully applied by the lecturer, to obtain the maximum benefit for all.

Practice tutorials were well received and students said: "I like the fact that I have multiple chances to complete our online tutorials. This enables us to learn from our previous mistakes and to be able to correct them."

They enabled students to check their understanding of the concepts taught. They created a space, in which students could feel confident with a particular concept - before engaging with the main tutorial. The immediate feedback informed students of their progress in the course. Some students called for more comprehensive feedback. A comprehensive feedback design should reflect opportunities for critical thinking and problem solving, to enhance learning. Students were positive about the prompt feedback. They believed that this enabled them to discover immediately where they had gone wrong; and why it was wrong. This is a very important feature of the online tutorial system. It could also be useful to have discussion forums available after each tutorial, for 
the students to share and discuss their areas of difficulty - or any issues they had experienced in their tutorials.

The practice tutorials allow for self-assessment and they assisted with test and examination preparation. Students were encouraged to work together and to assist each other and this fostered a culture of learning. These practice tests, together with the tutorial tests, were made available to students after the closing dates to use as preparation exercises. More time should be spent developing such practice tests, with appropriate feedback as it is clear that the practice tests enhance student learning. Positive comments received from students in respect of independent learning, understanding and practice reinforce the rationale of mastery learning used for setting up this online assessment learning environment. "The tutorials help you to check whether you know or understand your work".

While some students embraced the opportunity to work independently when and where it suited them, some did not experience the online environment as a good experience. Kerr, Rynearson and Kerr $(2006,101)$ identified "reading and writing skills, independent learning, motivation, and computer literacy" as four characteristics for "predicting online success". When assessing independent learning, they assessed the individual's "ability to manage time, balance multiple tasks, set goals, and their disposition regarding self-discipline, self-motivation, and personal responsibility" (Kerr et al. 2006, 101). They concluded that "students with high independent learning scores" also achieved "higher course grades" (Kerr et al. 2006, 101).

Convenience was one of the positive aspects emerging from students' comments. "I can access it any time I like and it is very convenient".

Other studies (Song et al. 2004; Kim, Liu and Bonk 2005), also identified convenience and flexibility, as advantages of online learning environments. Many negative comments centred on the lack of time and the need to be reminded of closing times. Research by Leidner and Jarvenpaa $(1995,286)$ suggested that students lacking self-discipline could prefer the "traditionally delivered mode".

Students said that the online tutorials helped them to work together with their friends - thereby maximizing their participation. It is important to clarify to students that they need to be active participants in their groups, and not simply to accept others' answers to tutorial problems.

To cater for diversity, assessment opportunities should include an additional variety of enriching and challenging assessments for those students who wish to be challenged. Badges could be awarded for any additional work done. This should encourage students 
who are not keen to immerse themselves further in the learning process, and to encourage them to move out of their comfort zones, and to negotiate more time on the task, as they attempt these additional challenging questions.

\section{The emotional learning environment}

Anxiety was a sub theme in the emotional learning environment. For some students, online assessment reduced stress levels since they could take the test when they were ready. Other students did not like the time limit placed on the tests. Some students distrusted the online marking system since no partial credit was awarded.

Practice tutorials assisted students in building confidence. Much has been written about confidence and mathematics in the literature. When students believed that they could do the mathematics, they felt passionate about it and they did more of it. Important lessons were learnt with regard to the value of these practice tests in increasing students' confidence, alleviating their anxieties, and allowing them to develop their capacity in Mathematics.

Students believed that the online tutorials supported them. "I find the online tutorials very helpful; and they give you a chance to practise and understand what you are actually doing"; and this fostered a positive attitude to learning.

Students enjoyed the confidentiality the online tutorial system afforded them; and one student said: "I feel comfortable when my marks are hidden from other students"; whilst another said: "I get lots of practice; and when I fail, only the marker and I know how badly I failed. I really like the confidentiality and the corrections that come with the right".

Students took responsibility for learning and managed their own learning in their own time and place that best suited their personal schedules. One student said: "It helps us learn during suitable times, according to our personal timetables".

Students felt positively about the high expectations set by the online tutorials, saying that it extended them; and "I learned to work faster and learn a lot in a short space of time. It has improved my mental processes in numerous ways."

Interventions to alleviate stressors, distrust and anxiety, could include: (1) design features, such as introductory presentations, training and demonstration sessions to familiarise students with the Moodle environment and specifically the different question types, student input responses and assessment conditions and requirements, (2) a demo test to complete before attempting the "real" assessments, and (3) in class, and online question and answer sessions, as well as enrichment discussions. 


\section{The virtual learning environment}

Under the theme of the virtual learning environment, the subthemes centred on personal computer set-up, assessment set-up, site navigation, computer literacy and user friendliness. Volery and Lord (2000) identified technology and the prior usage of technology, as success factors that should be present in e-learning. While Sun et al. (2008) maintain that computer illiteracy no longer exists in many countries, such as Taiwan and the Unites States; it is still a reality in developing countries, such as South Africa. Students arrive with differing computer literacy levels. Some students felt: "First help those students who never had an opportunity to have computers, help them to be able to get the moodle site". Whilst others said: "It is easy to use" and "I am completely fine with the online site".

Song, et.al. (2004) identified technical problems, as one of the biggest challenges experienced by participants in their study. In their study, some participants accepted the technical issues, while other participants felt the numerous technical issues were more significant. In this study, fewer computer literate students asked for additional assistance. A laboratory assistant was available to assist students at certain times. Demonstrating and hands on training to navigate and utilise the learning management system were not always an option, since not all venues are WIFI - enabled. Instead, detailed instructions and screenshots were emailed to students, in an effort to assist students to enrol and navigate the site. Positive comments were also made regarding the introduction of technology, such as: "It is a good way to learn; as the world is developing technologically. Thus, it helps us to grow and advance, hence the evolution of technology."

Introducing students to computers and the learning management system during an orientation week, could help such students to experience online learning more positively. Opportunities for discussion and reflection enrich the environment and encourage student participation and online engagement. Training and "how to" help are crucial to support students from a "just for you" individualised perspective.

The mathematics courses were supported by online tutoring and face to face supplementary instruction programmes in previous years; but because of a lack of interest, these were discontinued. As was suggested by student feedback, utilising online discussions in Moodle might support and enrich student learning.

Some elements listed under the virtual environment, namely, computer set-up, navigation, assessment set-up, and user friendliness correspond with critical factors, such as technology and the previous use of technology for online delivery, as listed by Volery 
and Lord (2000). Under the Technology criterion, Volery and Lord (2000) list "ease of access and navigation, interface design and level of interaction". Sun et al. (2008) identified "seven critical factors", which impact "learners" perceived satisfaction". One of the factors they identified affecting user satisfaction was ease of use. Factors, such as computer setup, site navigation, assessment setup identified in the present study under the virtual environment, impact the user friendliness, and thus students' satisfaction with the online assessment system. Sun et al. (2008) refer to the impact of technological design on students' satisfaction, as well as the negative impact of computer anxiety on students' enjoyment of e-learning. They recognise the importance of assessment in e-Learning, when they state: "The courses must be designed in co-ordination with assessment, in order to achieve the best results (Sun et al. 2008, 1196)".

Online assessment is ideally suited for large class tutorial assessments. The need for mark administration and marking is eliminated, thereby allowing lecturers to focus on teaching and learning. Timeous feedback allows the students to do regular selfassessment. Flexibility of time and location allow for self-paced, independent learning to occur. Maximising positive aspects and minimising negative aspects could provide a more supportive, improved online environment. Positive aspects that emerged from the research are flexibility and the convenience to work when and where it suits the students, independent learning and improved understanding made possible by the online resources. These are of particular importance to enhance teaching, learning and assessment in large classes. Although some improvements are necessary, it would seem that the majority of students benefited from online assessment and preferred it to schedule face to face tutorial classes.

Some suggestions are presented for the next cycle. A supportive environment for online assessment should address the following issues: Aspects of the online assessment environment requiring refinement are: feedback, assessment setup, online assessment design, and the user friendliness of the assessment system. It would be beneficial to all students, especially those who feel less computer literate, if they could be given an introductory hands on training session using the relevant Moodle course, to access and navigate the learning management system (LMS), and to do a demo online assessment, during orientation. This would benefit all the lecturers and students making use of the LMS. Increasing computer laboratory space is subject to financial constraints, but the BYOD (bring your own device) approach has already taken off; and it should be encouraged. It would also be useful if students could be given a short time management course during their orientation. 


\section{CONCLUSION}

Addressing the teaching, learning and assessment challenges experienced in large classes will have to become a priority if we are to engage with quality education for future generations of students. This research has shown that online assessment for mastery learning in mathematics can be an invaluable part of teaching and learning, particularly in large classes. Its design and implementation will however require careful consideration so that it empowers all the students in the class to engage with and learn mathematics.

This study drew on students' self-reported experiences and comments regarding online assessment within a mastery learning approach, in order to consolidate elements which are important for a supportive learning environment for online assessment. In an attempt to distill these findings into a useful framework, the findings were clustered into important building blocks in each pillar. This gives rise to the " 4 pillar Supportive Online Assessment Framework". Under each pillar, a number of elements are identified; and each of these should be present (see Figure 2) when an online assessment system is being developed. The SOA framework could inform guidelines and policy for design, development, implementation, evaluation and best practices for online assessment.

The study reported here, not only concurs with the 3 pillar themes important for a supportive environment, as identified by Padayachee et al. (2014); but it also shows that within the context of online assessment, a number of additional important elements should be included. Furthermore, it shows that a fourth pillar, namely that of the virtual environment, is crucial; and it includes specific elements that are vital for the supportive online assessment environment. The SAO framework could be used not only for formative online assessments but also summative online assessments.

Findings from this study indicate that a number of design aspects may contribute to student success. These include: (1) appropriate timeframe to develop high quality questions, question banks, and a variety of questions from multiple resources; (2) a flexible integrated approach to expand in more than one module; (3) optimum use of automated system feedback; (4) reduced assessment anxiety through communication with students on the basic assessment principles, such as fairness, unbiased assessment implementation, system integrity; and (5) the formative and developmental nature of the online assessments.

Online assessment is gaining momentum in higher education and there is not sufficient emphasis on what should be in place to support students and enhance student experience in this regard. Knowledge gained from this study could inform online 


\section{ONLINE ASSESSMENT}

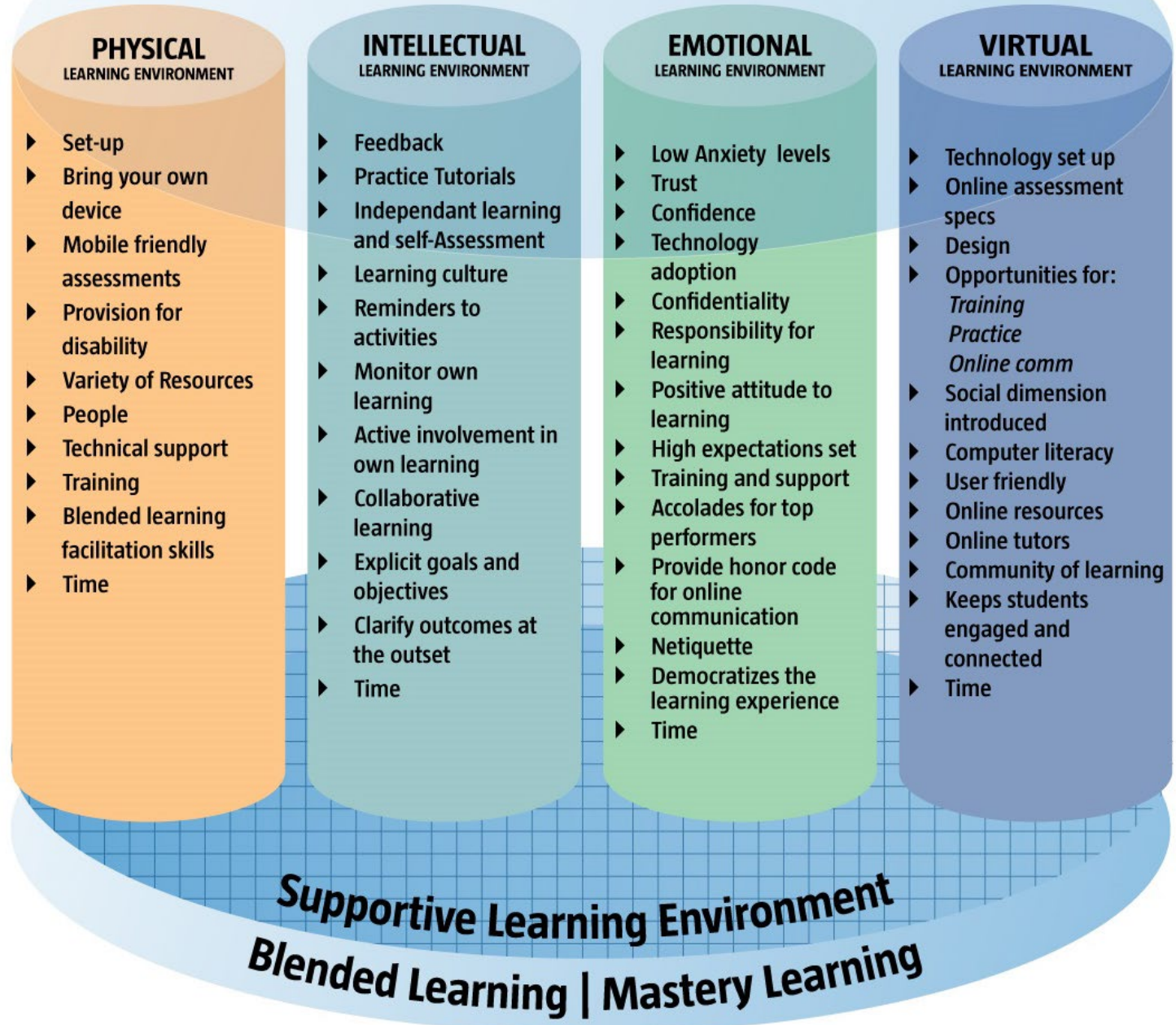

Figure 2: The 4 Pillar Supportive Online Assessment (SAO) Framework

assessment design and contribute to an improvement of online assessment practices in higher education e.g. online tutorials and formative assessment opportunities are key drivers for student learning and success. It is important for those designing online assessment environments to remember that online assessment is multi-faceted and therefore needs a holistic approach, good planning and purpose driven design and support from all relevant role players e.g. stable Learning Management System, technical support, enabled networks, helpdesk, fit for purpose assessment design, integrated learning and assessment tasks and opportunities.

This research has the potential to influence not only online assessment of mathematics but also other disciplines in higher education. The research findings of this 
study are comprehensive and should inform the development of guidelines, strategies and policies for online assessment. Furthermore, these findings not only contribute to the body of online assessment knowledge, but could inform online assessment practices. To stay relevant in the dynamic online teaching, learning and assessment environments, further research studies in the field of online assessment are of the utmost importance.

\section{REFERENCES}

Abedi, R. 2014. International Association for Educational Assessment. Singapore 40th Annual Conference. http://www.iaea.info/documents/paper_371f3ab4.pdf (Accessed on 11 September 2016).

Allen, E. and J. Seaman. 2014. Grade change: Tracking online education in the United States. Babson Survey Research Group Report. http://sloanconsortium.org/publications/survey/ grade-change-2013 (Accessed on 9 September 2016).

Anderson, L. W. 1975. Major assumptions of mastery learning. Annual Meeting of the Southeast Psychological Association. ERIC Online. http://files.eric.ed.gov/fulltext/ ED150172.pdf (Accessed on 18 April 2016).

Anderson, T. 2004. Teaching in an online learning context. Athabasca University. http://cde.athabascau.ca/online_book/ch11.html (Accessed on 19 April 2016).

Bloom, B. S. 1968. "Learning for Mastery" UCLA - CSEIP - Evaluation Comment.

Cowan, J. 2005. Designing assessment to enhance student learning. http://www.heacademy. ac.uk/assets/ps/documents/practice_guides/practice guides/ps0069_designing_assessment to_improve_physical_sciences_learning_march_2009.pdf (Accessed 2010) and http://www.enhancementthemes.ac.uk/docs/workshop/designing-assessment-to-enhancestudent-learning-paper.pdf (Accessed on 15 August 2017).

Davis, D. and J. Sorrell. 1995. Mastery learning in public schools. Educational Psychology Interactive. Valdosta, GA: Valdosta State University. http://www.edpsycinteractive.org/ files/mastlear.html (Accessed on 11 September 2016).

Engelbrecht, M. 2005. Adapting to changing expectations: Postgraduate students' experience of an e-learning tax program. Computers \& Education 45: 217-229.

Gibbs, G., 1999. Using assessment strategically to change the way students learn. In Assessment Matters in Higher Education, ed. S. Brown and A. Glasner, 41-53. Society for Research in Higher Education and Open University Press, Buckingham.

Groen, L., M. Coupland, T. Langtry, J. Memar, B. Moore and J. Stanley. 2015. The mathematics problem and mastery-learning for first-year, undergraduate STEM students. International Journal of Learning, Teaching and Educational Research 11(1): 141-160.

Guskey, T. R. 2008. Chapter 21: Mastery Learning in 21st century education: A reference handbook. Vol. 1, ed. T. L. Good. Sage Thousand Oaks, CA: Publication.

Holtz, F. 2006. Enhancing supportive-learning environments and student achievement through Project ALERT. http://daretodifferentiate.wikispaces.com/file/view/319_EnhancingSLE_ and_SA.pdf (Accessed on 7 August 2016).

Inui, T. S. 2015. The charismatic journey of mastery learning. Academic Medicine 90(11): 14271575.

Kauffman, H. 2015. A review of predictive factors of student success in and satisfaction with online learning. Research in Learning Technology Vol 23.

Kerr, M. S., K. Rynearson and M. C. Kerr. 2006. Student characteristics for online-learning success. Internet and Higher Education 9: 91-105. doi:10.1016j.iheduc.2006.03.002. 
Kim, K. J., S. Liu and C. J. Bonk. 2005. Online MBA students' perceptions of online learning: Benefits, challenges, and suggestions. Internet and Higher Education 8: 335-344. ELSEVIER 8: doi:10.1016/j.iheduc.2005.09.005.

Kulik, C. L., J. A. Kulik and J. Bangert-Drowns. 1990. Effectiveness of mastery-learning programs: A meta-analysis". Review of Educational Research 60(1): 265-299. doi:10.3102/00346543060002265.

Leidner, D. E. and S. L. Jarvenpaa. 1995. The use of information technology to enhance management school education: A theoretical review. MIS Quaterly 19(3): 265-291. http://www.jstor.org/stable/249596

Liaw, S. S., H. M. Huang and G. D. Chen. 2007. Surveying instructor and learner attitudes toward e-learning. Computers \& Education 49: 1066-1080.

Machado, M. and E. Tao. 2007. Blackboard vs moodle: Comparing user experience of learning management systems. Global Engineering: Knowledge Without Borders, Opportunities Without Passports: S4J-7-S4J-12.

Manchester, H., S. Ralph and O. Shipova. 2005. The teacher's role in using WebCT as a communication tool with postgraduate students. The International Journal of Learning 12(4): 101-107.

McGaghie, W. C. 2015. Mastery learning: It is time for medical education to join the 21st century. Academic Medicine 90(11): 1438-1441. doi:10.1097/ACM.000000000000911.

Norberg, A., C. Dzuiban and P. D. Moskal. 2011. A time-based blended-learning model. On the Horizon 19(3): 207-216.

Padayachee, P., H. Boshoff, W. Olivier and A. Harding, 2011. A blended learning Grade 12 intervention using DVD technology to enhance the teaching and learning of mathematics. Pythagoras 32(1), Art. \#24, 8 pages. http://dx.doi.org/10.4102/pythagoras.v32i1.24 http://www.pythagoras.org.za/index.php/pythagoras/rt/printerFriendly/24/44

Padayachee, P. 2010. A case study: Exploring a DVD-driven approach for teaching and learning mathematics, at secondary school level, with a framework of blended learning. Unpublished $\mathrm{PhD}$ thesis. Nelson Mandela Metropolitan University.

Padayachee, P., H. Boshoff, A. Harding and H. Johannes. 2014. Elements of a supportive learning environment for mathematics learners. International Research in Education 2(2): 33-49.

Reason, P. and H. Bradbury. 2007. The SAGE handbook of action research: Participative inquiry and practice. Sage Pubns Ltd.

Rossouw, D. 2009. Educators as action researchers: Some key considerations. South African Journal of Education. EASA Vol 29: 1-16.

SAQA. 2014. South African Qualifications Authority Standard Glossary of Terms. SAQA, April 2014. http://hr.saqa.co.za/glossary/pdf/5WBCVgxsLsdKRmta/Glossary\%20of\%20terms \%20(April\%202014).pdf (accessed on 5 April 2016).

Song, L., E. S. Singleton, J. H. Hill and M. H. Koh. 2004. Improving online learning: Student perceptions of useful and challenging characteristics. The Internet and Higher Education 7: 59-70. ELSEVIER. doi:10.1016/j.iheduc.2003.11.003.

Sorensen, E. 2013. Implementation and student perceptions of e-assessment in a Chemical Engineering module. European Journal of Engineering Education 38(2): 172-185. http://www.tandfonline.com/doi/abs/10.1080/03043797.2012.760533\#.VxS3cvl97IU (Accessed 18 April 2016).

Sun, P. C., R. J. Tsai, G. Finger, Y. Y. Chen and D. Yeh. 2008. What drives a successful elearning? An empirical investigation of the critical factors influencing learner satisfaction. Computers \& Education 50(4): 1183-1202.

Standard Glossary of Terms. SAQA, April 2014. http://hr.saqa.co.za/glossary/pdf/5WBCV gxsLsdKRmta/Glossary\%20of\%20terms\%20(April\%202014).pdf (Accessed on 5 April 2016). 
The Framework for 21st Century Learning. n.d.: http://www.p21.org/our-work/p21-framework (Accessed on 11 September 2016).

Tilghman, S. B. 2011. Designing and developing online-course assessments. Review of Higher Education and Self-learning 4(9): 31-34

Volery, T. and D. Lord. 2000. Critical success factors in online education. International Journal of Educational Management 14(5): 216-223. http://dx.doi.org/ $10.1108 / 09513540010344731$ 


\section{Appendix A}

Table 1: Physical learning environment

\begin{tabular}{|c|c|}
\hline \multicolumn{2}{|r|}{ Physical learning environment } \\
\hline Description & Results and interpretation \\
\hline $\begin{array}{l}\text { Classroom teaching and } \\
\text { learning blended with online } \\
\text { resources include textbooks, } \\
\text { additional resources and } \\
\text { materials }\end{array}$ & $\begin{array}{l}\text { Two hundred and fifteen students }(55 \%) \text { stated that the } \\
\text { additional resources placed on the Moodle site were } \\
\text { beneficial to them }\end{array}$ \\
\hline Course access & $\begin{array}{l}\text { Only one hundred and seventy-one students }(44 \%) \\
\text { accessed their course site from an NMMU computer } \\
\text { laboratory }\end{array}$ \\
\hline Venues & $\begin{array}{l}\text { Some students experienced crowding of the venues; whilst } \\
\text { others did not. } \\
\text { "I am happy with how the tutorials are done; because there } \\
\text { are labs open for those who need assistance." } \\
\text { "I don't always have time to access the internet; as the labs } \\
\text { are always full; and I don't have any other access besides } \\
\text { the labs." }\end{array}$ \\
\hline $\begin{array}{l}\text { Important elements in a } \\
\text { supportive-physical } \\
\text { environment for online } \\
\text { assessment }\end{array}$ & $\begin{array}{l}\text { Availability of own electronic devices - fifty per cent of the } \\
\text { students had access to laptops; and } 32 \% \text { had access to } \\
\text { smartphones, which adds an element of mobility, which } \\
\text { connects with the virtual-learning environment by } \\
\text { extending the physical classroom into an online space not } \\
\text { bound by time, space or distance. }\end{array}$ \\
\hline $\begin{array}{l}\text { Students' self-reported } \\
\text { comments on the positive } \\
\text { aspects of the physical } \\
\text { learning environment. }\end{array}$ & $\begin{array}{l}\text { Blending the face-to-face with the online environment, } \\
\text { provides flexible engagement, - time, - choices and } \\
\text { numerous opportunities to re-take online assessments. } \\
\text { The online-assessment design enhanced learning through } \\
\text { self-regulation, self-assessment and self-paced formative- } \\
\text { assessment opportunities. } \\
\text { "I enjoyed being able to answer the questions on my own } \\
\text { time, according to the deadline. I liked that I had the choice } \\
\text { to do it in an IT lab at university, or at home. It was great that } \\
\text { the extra work counted towards bonus marks." }\end{array}$ \\
\hline Relevant issues & $\begin{array}{l}\text { Lack of computer laboratory space and network-related } \\
\text { issues, such as the lack of internet access and Wi-Fi } \\
\text { connectivity. }\end{array}$ \\
\hline $\begin{array}{l}\text { People in various capacities } \\
\text { were indicated as important }\end{array}$ & $\begin{array}{l}\text { Lecturers; technical and student assistants; peers; and } \\
\text { student groups were indicated as important. Students also } \\
\text { requested that tutors be made available. } \\
\text { "People tend to do the quizzes and tutorials as a group; as } \\
\text { no lecturer or invigilator is present." } \\
\text { "By opening a group chat where students can interact and } \\
\text { help each other, whenever the need arises." }\end{array}$ \\
\hline
\end{tabular}




\section{Appendix A}

Table 2: The Intellectual Learning Environment

\begin{tabular}{|c|c|}
\hline \multicolumn{2}{|r|}{ Intellectual environment } \\
\hline Description & Results and interpretation \\
\hline Practice tests & $\begin{array}{l}\text { Two hundred and seventy-one students (69\%) felt that they } \\
\text { had benefited by doing the practice tests. The practice tests } \\
\text { were set up, in addition to the tutorial test. The students were } \\
\text { to attempt these tests first, and upon obtaining more than } 70 \% \\
\text { in the practice tests, the students were allowed to attempt the } \\
\text { tutorial test. Two hundred and seventy-four students ( } 70 \%) \\
\text { appreciated the flexibility offered by online tutorials, while } 28 \% \\
\text { preferred scheduled tutorial periods. Only eighty-six students } \\
(22 \%) \text { stated a preference for paper-based tests. }\end{array}$ \\
\hline Own device & $\begin{array}{l}\text { Eighty-eight per cent of the students reported that they owned } \\
\text { their own device, or could assess a device outside the } \\
\text { university computer laboratories. The response to this question } \\
\text { raised the issue that students owning such equipment were } \\
\text { more likely to be computer-literate, and should find it easier to } \\
\text { access the online environment. }\end{array}$ \\
\hline \multirow[t]{2}{*}{ Positive aspects } & $\begin{array}{l}\text { Positive aspects centred on the flexibility online assessment } \\
\text { allowed, as shown by this student's comment: } \\
\text { "Very flexible - can be done anywhere, not even on campus, } \\
\text { even at midnight, you can work, you do it, according to your own } \\
\text { schedule; and that really is a plus." }\end{array}$ \\
\hline & $\begin{array}{l}\text { Students were positive about the resources available online; } \\
\text { and they said that it helped them to keep track of the concepts } \\
\text { covered; it allowed them to manage their own learning; and } \\
\text { they requested more resources, especially that more tutorial } \\
\text { questions be placed on the site. Students were positive that } \\
\text { the online assessment allowed them to prepare for written } \\
\text { tests and examinations, as revealed by this student's } \\
\text { comments: } \\
\text { "The positive aspect is that it is perfect preparation for tests to be } \\
\text { written; and it contributes to studying and understanding the } \\
\text { work." }\end{array}$ \\
\hline Independent learning & $\begin{array}{l}\text { The prevalent comments here centred on independent } \\
\text { learning, emphasising the positive outcomes of a mastery- } \\
\text { learning approach in a blended-learning environment. } \\
\text { Participants embraced the opportunity to manage their own } \\
\text { learning and to improve their understanding by being able to } \\
\text { work - when and where it suited them - and not being tied to a } \\
\text { fixed tutorial period, as illustrated by the following students' } \\
\text { comments: } \\
\text { "It helps us learn during suitable times, according to our personal } \\
\text { timetables." } \\
\text { "I can access it any time I like; and therefore, it is very } \\
\text { convenient." } \\
\text { "It helped me to understand the work better." }\end{array}$ \\
\hline Positive statements & $\begin{array}{l}\text { "It helps me to better prepare and understand the module." } \\
\text { "The tutorials and the quizzes have increased my understanding } \\
\text { of certain sections, which is beneficial to me." }\end{array}$ \\
\hline
\end{tabular}




\section{Appendix A}

Table 3: The Emotional Learning Environment

\begin{tabular}{|c|c|}
\hline \multicolumn{2}{|r|}{ Emotional-learning environment } \\
\hline Description & Results and interpretation \\
\hline Benefits & $\begin{array}{l}\text { Two hundred and fifty-nine students ( } 66 \%) \text { welcomed the } \\
\text { confidentiality of online assessment. } \\
\text { Just more than half ( } 57 \%) \text { of the students reported that } \\
\text { they enjoyed the online tutorials. } \\
\text { Students were appreciative of the high expectations set by } \\
\text { the online tutorial system, which challenged them, as one } \\
\text { student said: } \\
\text { "I learned to work faster and learn a lot in a short space of } \\
\text { time. It has improved my mental processes in numerous } \\
\text { ways." }\end{array}$ \\
\hline Positive aspects & $\begin{array}{l}\text { Positive aspects centred on the good experience } \\
\text { presented by the online assessment for students. } \\
\text { Students said that they gained confidence, as a result of } \\
\text { the online assessment since: } \\
\text { "It gave me extra practice, which gave me confidence. It } \\
\text { gave me extra practice; and I could spot where I didn't } \\
\text { understand." } \\
\text { Some students were better able to come with the } \\
\text { unknown, and to embrace technology, as illustrated by the } \\
\text { following comments: } \\
\text { "First, help those students who never had an opportunity to } \\
\text { have computers; help them to be able to get into the Moodle } \\
\text { site." } \\
\text { "The online has improved my computer skills; as I am faster } \\
\text { when using the PC than before and have learned so much." }\end{array}$ \\
\hline Negative aspects & $\begin{array}{l}\text { Negative aspects centred on the students distrusting } \\
\text { electronic marking; and dissatisfaction that no partial } \\
\text { credit was awarded for questions that were partially } \\
\text { correct. Some students said that doing assessment online } \\
\text { helped alleviate their anxiety; whilst others said that it } \\
\text { added to theirs, as illustrated by these various comments: } \\
\text { "You get to take the test when you are ready and alone; and } \\
\text { there isn't any pressure." } \\
\text { "Learning online puts me under a lot of pressure; as it is } \\
\text { timed sometimes." } \\
\text { Some students, who were computer-illiterate experienced } \\
\text { difficulty when confronted with Moodle. }\end{array}$ \\
\hline
\end{tabular}




\section{Appendix A}

Table 4: The Virtual Learning Environment

\begin{tabular}{|c|c|}
\hline \multicolumn{2}{|r|}{ Virtual Learning Environment } \\
\hline Description & Results and interpretation \\
\hline Access & $\begin{array}{l}\text { The majority of students have access to an internet } \\
\text { connection. Two hundred and twenty-eight students ( } 58 \%) \\
\text { reported that their connection speed was slow; whilst fifty- } \\
\text { five students (14\%) experienced a loss of connection; and } \\
\text { they had difficulty in completing the tasks. Moodle allows } \\
\text { the lecturer to restrict the number of attempts; and to set } \\
\text { penalties for more than an allotted number of attempts. } \\
\text { Tasks not completed ahead of schedule, could cause } \\
\text { students to exceed their allocated number of submission } \\
\text { attempts, if the system is not set-up properly. }\end{array}$ \\
\hline Moodle environment & $\begin{array}{l}\text { Three hundred and thirty-three participants (85\%) had } \\
\text { accessed Moodle prior to the start of their courses. This } \\
\text { would lead one to believe that students who experience } \\
\text { access-related problems were less computer literate; and } \\
\text { probably did not have any previous Moodle experience. }\end{array}$ \\
\hline Benefits & $\begin{array}{l}\text { Two hundred and seventy-one students ( } 69 \%) \text { felt that } \\
\text { they had benefited by doing the practice tests. Two } \\
\text { hundred and seventy-four students ( } 70 \%) \text { appreciated the } \\
\text { flexibility offered by online tutorials; while } 28 \% \text { preferred } \\
\text { scheduled tutorial periods. Only eighty-six students }(22 \%) \\
\text { stated a preference for paper-based tests. Two hundred } \\
\text { and fifteen students ( } 55 \% \text { ) stated that the additional online } \\
\text { material had been beneficial to them. }\end{array}$ \\
\hline Positive aspects & $\begin{array}{l}\text { Students' self-reported comments on positive aspects of } \\
\text { the virtual-learning environment centred on the system's } \\
\text { user-friendliness, and the computer literacy with which the } \\
\text { online assessment empowered students. }\end{array}$ \\
\hline Negative aspects & $\begin{array}{l}\text { Whereas the negative aspects focus on Moodle's } \\
\text { navigational issues and assessment set-up issues, as well } \\
\text { as a lack of user-friendliness of the Moodle site. Students } \\
\text { suggested a social dimension by stating: } \\
\text { "Perhaps you could include a chat-room; where students } \\
\text { can exchange ideas and assist one another, where needs } \\
\text { be." }\end{array}$ \\
\hline $\begin{array}{l}\text { Online assessment } \\
\text { network }\end{array}$ & $\begin{array}{l}\text { The online assessment network within a blended mastery- } \\
\text { learning environment provided opportunities for online } \\
\text { practice and online tutorial tests to master the course } \\
\text { content. Practice tests were experienced, as resources for } \\
\text { online assessments. Flexible time options for students to } \\
\text { Bring Your Own Device (BYOD), or make use of computer } \\
\text { laboratories for online assessment, were perceived as } \\
\text { supportive for learning. }\end{array}$ \\
\hline
\end{tabular}

